\title{
Making vulnerability visible: medical repatriation and Canada's migrant agricultural workers
}

\author{
Jenna L. Hennebry PhD, Gabriel Williams MA
}

See also CMAJ Open, www.cmajopen.ca/lookup/doi/10.9778/cmajo.20140014

$\mathrm{T}$ he long-standing Seasonal Agricultural Worker Program (SAWP) has drawn considerably less public criticism than other streams of the Temporary Foreign Worker Program (TFWP) that have captured media attention in recent years, despite mounting evidence against its deeply flawed structures that render migrant agricultural workers vulnerable to exploitation and health risks. Making a substantial contribution to this evidence base, the CMAJ Open article by Orkin and colleagues ${ }^{1}$ analyzes hitherto inaccessible data on repatriations of migrant workers, a phenomenon with transnational health implications. This novel research can help inform new regulatory frameworks around health care, compensation and service provision, as well as methods of collecting program data, which are currently performed in the private domain. We have focused our comments on the structural issues of repatriation and employer control, data collection and access, and the difficulties in both estimating and addressing the health and social needs of the vulnerable population of migrant agricultural workers.

In 2013, 221273 foreign workers entered Canada under both the TFWP and the International Mobility Program, of whom 27566 entered or re-entered as part of the SAWP. ${ }^{2}$ The chronic health effects facing many migrant agricultural workers are of great concern for researchers, migrant rights advocates and scholars. $^{3-6}$ In Canada, the practice of repatriating workers who have been injured and "naming" people for future participation in the program increases employer control, the dependency that migrant workers have on the program and the likelihood that workers will not seek treatment for medical conditions or injuries. Experts and government officials gathered to offer testimony on the violations of workers' labour and human rights under the SAWP before a recent hearing of the Human Rights Tribunal of Ontario. ${ }^{7}$ The tribunal accepted that workers are reluctant to complain about their employers, injuries or safety standards for fear of repatriation; that workers are rendered uniquely vulnerable because of their closed relationship with their employers; and that the structure of the program leads to precariousness of the workers. ${ }^{7}$ The structures of the program create the conditions for workers' increased vulnerability to health risks, particularly because workers' lives (and access to essential services and protections) are closely controlled and tied to the employers. ${ }^{4,8}$

Medical repatriation and the naming system exacerbate barriers to health care for migrant agricultural workers, because fear of repatriation and lack of reporting injuries contribute to workers' reticence to seek care while in Canada. For those who are repatriated, opportunities to seek care or compensation from provincial insurance systems (e.g., Ontario's Workplace Safety and Insurance Board) are lost once they return home. An overwhelming body of evidence from surveys and interviews with migrant workers, health care practitioners and community service providers points to systemic vulnerabilities of migrant farm workers, with contributing factors being barriers to health care access, employment and legal precarity, and dependency.,8 Although the program is often framed as a "win-win-win"

\section{KEY POINTS}

- Mounting evidence shows that Canada's Seasonal Agricultural Worker Program is deeply flawed, leaving workers vulnerable to exploitation and health risk.

- The practice of repatriating workers who become ill or injured exacerbates barriers to health care for these workers, and data on such repatriations in Ontario are collected and controlled by a private employers' group.

- These data, released by the Human Rights Tribunal of Ontario, have allowed Orkin and colleagues to open the door to improved understanding of the vulnerability of migrant workers.

- This transparency should be maintained to ensure that the labour and human rights of migrant agricultural workers are upheld. 
for Canada, the sending countries and the migrants themselves, the developmental rhetoric is contrasted by these realities and the increased precarity and vulnerability perpetuated by the naming and early termination clauses of the program (in particular, medical repatriation).

For decades, researchers, and more recently health care providers and public health representatives, have struggled to gain access to detailed data on migrant agricultural workers. In general, data on entries at a detailed geographical level, repatriations and complaints have not been publicly available from governments. Yet, in Ontario, a nonprofit private organization comprising growers' association representatives, the Foreign Agricultural Resource Management Services (FARMS), keeps detailed records of medical repatriations of migrant agricultural workers as part of their integral role in the management of the SAWP. ${ }^{9}$ Despite an awareness that data were being collected on entries, re-entries, type of crop, size of farm, naming (or repeat hiring) and repatriations, no direct avenue for accessing such data was available, primarily because FARMS is a private sector organization. As such, it has no obligation to share data publicly or accede to freedom of information requests without a court order. ${ }^{9-11}$ Orkin and colleagues were able to access these data because it became publicly available as evidence in the tribunal. At that time, a request was issued to FARMS to release medical repatriation data on migrant agricultural workers. ${ }^{1,7}$ The resulting report, based on data received from the Freedom of Information Coordinator at Social Justice Tribunals Ontario in 2011, provided ground-breaking access to a new source of data, and Orkin and colleagues' coding and assessment of these repatriation data by medical practitioners provides unrivalled evidence of the transnational vulnerability of migrant agricultural workers in Canada.

These data were brought to public light through the tribunal, but they should continue to be made available. The lack of transparency in accessing these most basic and vital data for improving health and rights is truly appalling, and frankly should be embarrassing to governments in this period of evidence-based policy. Furthermore, without public access, scrutiny and evaluation, the potential of these data remain limited owing to the weakened validity and reliability of the dataset when it is open to manipulation by employers and has no oversight mechanism to ensure reliability or accuracy throughout the data collection process. Thus, these data represent the only data set available to assess the indicators of medical repatriation and are of landmark importance.

Orkin and colleagues' work has opened the door to improved understanding of the vulnerability of agricultural workers. This transnational vulnerability was hitherto argued by researchers using anecdotal evidence and qualitative case studies; these data make visible the undeniable costs of becoming ill or injured in the SAWP. This study ought to provoke wider discussion on the structures of the SAWP and spark public outrage over the health risks faced by migrant workers, the lack of transparency with regard to this vulnerable population and the inhumane practice of medical repatriation.

\section{References}

1. Orkin A, Lay M, McLaughlin J, et al. Medical repatriation of migrant farm workers in Ontario: a descriptive analysis. CMAJ Open 2014; 2:E192-8.

2. Facts and figures 2012 - Immigration overview: Permanent and temporary residents. Ottawa: Citizenship and Immigration Canada; [modified 2014]. Available: www.cic.gc.ca/english/ resources/statistics/facts2012/temporary/03.asp (accessed 2014 Oct. 10).

3. Preibisch K, Hennebry J. Temporary migration, chronic effects: the health of international migrant workers in Canada. CMAJ 2011;183:1033-8.

4. McLaughlin J, Hennebry J, Haines T. Paper versus practice: occupational health and safety protections and realities for temporary foreign agricultural workers in Ontario. Perspectives interdisciplinaires sur le travail et la santé 2014;16-2.

5. Preibisch K, Otero G. Does citizenship status matter in Canadian agriculture? Workplace health and safety for migrant and immigrant laborers. Rural Sociol 2014;2:174-99.

6. McLaughlin J, Hennebry J. Pathways to precarity: structural vulnerabilities and lived consequences for migrant farmworkers in Canada. In: Goldring L, Landolt P, editors. Precarious migratory status. Toronto: University of Toronto Press; 2013.

7. Peart v. Ontario. HRTO 611 (CanLII). Available: http://canlii.ca $/ \mathrm{t} / \mathrm{g} 6 \mathrm{qb5}$ (accessed 2014 Sept. 2)

8. Hennebry JL. Permanently temporary? Agricultural migrant workers and their integration in Canada. Montréal: Institute for Research on Public Policy; 2012.

9. Hennebry JL. Bienvenidos a Canadá? Globalization and the migration industry surrounding temporary agricultural migration in Canada. Can Stud Popul 2008;35:339-56.

10. Personal Information Protection and Electronic Documents Act (PIPEDA) [factsheet]. Guelph (ON): Ministry of Agriculture, Food and Rural Affairs; [modified 2014]. Available: www .omafra.gov.on.ca/english/rural/facts/05-049.htm\#3 (accessed 2014 Sept. 2).

11. Freedom of Information and Protection of Privacy Act (FIPPA). R.S.O. 1990, CHAPTER F.31. Available: www.e-laws.gov.on.ca $/ \mathrm{html} /$ statutes/english/elaws_statutes_90f31_e.htm (accessed 2014 Sept. 2)

Affiliations: International Migration Research Centre, Wilfrid Laurier University, Waterloo, Ont.

Contributors: Both of the authors contributed substantially to the conception and writing of the article, approved the final version submitted for publication and agreed to act as guarantors of the work. 